\title{
Research on Real Estate Bubble Measurement and Prevention Countermeasures in Guangzhou City
}

\author{
Manzi Ji \\ College of Public Administration, Jinan University, Guangzhou, China \\ Email: jimanzijnu@163.com
}

How to cite this paper: Ji, M.Z. (2018) Research on Real Estate Bubble Measurement and Prevention Countermeasures in Guangzhou City. Open Journal of Social Sciences, 6, 28-39.

https://doi.org/10.4236/jss.2018.611003

Received: October 12, 2018

Accepted: November 5, 2018

Published: November 8, 2018

Copyright $\odot 2018$ by author and Scientific Research Publishing Inc. This work is licensed under the Creative Commons Attribution International License (CC BY 4.0).

http://creativecommons.org/licenses/by/4.0/

\section{(c) (i) Open Access}

\begin{abstract}
The purpose of this paper is to analyze whether the real estate industry in Guangzhou will have a bubble phenomenon with the rapid rise in housing prices. This issue has also become the focus of public concern and has great practical significance for maintaining social stability and healthy economic development. This paper adopts the research methods of single index and comprehensive index, and uses Guangzhou data from 2007 to 2017 to analyze the existence and measurement of real estate bubble. According to the empirical results, this paper further elaborates the causes of the bubble. The results indicate that: 1) The study chooses a measurement indicator and constructs a real estate bubble measurement system from the perspectives of supply and demand, investment, and credit. 2) Whichever method is used, the measurement results indicate that exists a bubble, and it shows a clear upward trend. It's concluded that: 1) There are many causes of the real estate bubble in Guangzhou, including imbalances in supply and demand, land costs, speculation, and financial expansion, et al. 2) The measurement results of the Guangzhou real estate bubble can provide relevant evidence for the government to formulate policies or means to curb the economic bubble.
\end{abstract}

\section{Keywords}

Real Estate Bubble, Measurement, Cause Analysis, Guangzhou City

\section{Introduction}

Since China cancelled the welfare housing system in 1998, the real estate industry has taken this opportunity as a rapid marketization, and has also promoted the increase in the output value of related industries, which has played a consi- 
derable role in stimulating economic growth and urbanization. Especially in the 21 st century, the development of real estate has prospered all the way, and then house prices have risen rapidly. Housing problems have always been related to people's livelihood, so the topic of "Does there is a bubble in real estate?" became the focus of the moment. In order to curb the housing prices that are rising too fast, the government has also actively introduced control measures, and the rate of increase in housing prices has also been controlled. However, this does not perfectly solve the current "holes in the property market". The behavior of real estate speculation in the market has become a major problem in raising housing prices. After all, China's housing prices are still rising, especially for large cities with large populations.

As a first-tier city China, Guangzhou has a population of more than 14 million. For the common people, the solution to the housing problem is particularly important. In recent years, the real estate industry in Guangzhou has developed at a high speed, but it has also reflected many problems, such as the rapid rise in housing prices, the frequent occurrence of speculation, and the imbalance between supply and demand. As we all know, the development of a city needs to be supported by the real economy. Once the capital has experienced the collapse of excessively high, it will undoubtedly bring serious negative effects and influences to the whole society. Therefore, in the face of the current real estate market in Guangzhou, whether it has a bubble is very worthy of attention. Is there a bubble in the real estate market in Guangzhou? If so, what is the level of the economic bubble? How did the bubble develop?

\section{Measurement of Guangzhou Real Estate Bubble}

\subsection{Analysis of Current Situation of Real Estate Market}

As the provincial capital of Guangdong Province, Guangzhou has the status of a first-tier city in China. The region's GDP ranks among the top in the country, from 714 billion Yuan in 2007 to 2105.03 billion Yuan in 2017. The annual growth rate is over $7 \%$ in the past decade. The real estate industry as a pillar industry has a significant contribution to GDP. The proportion of the added value of the real estate industry in Guangzhou has increased year by year since 2007, and reached a peak of $8.29 \%$ in 2016 . According to statistics, the urbanization rate of Guangzhou in 2017 was $86.14 \%$, and the number of registered households reached 180,600. The house is the material basis of the people's life, and the increase in house prices naturally affects people's living standards. By analyzing the current situation of the real estate market in Guangzhou, this paper will focus on the real estate development investment situation and the average price of commercial housing.

Real estate development investment: From 2007 to 2017, the total investment in fixed assets of Guangzhou's society was generally rising, from 186.334 billion yuan to 591.983 billion yuan, and the average annual growth rate was $12.24 \%$. At the same time, the total investment in real estate development continued to rise, from the initial 70.38 billion yuan to 270.289 billion yuan in 2017 . 
In particular, in 2010 and 2011, the amount of real estate investment rose rapidly, but the increase rate still reach $20.30 \%$ and $32.80 \%$. After that, it fell back, but it was basically in a steady state. The average annual growth rate of real estate investment was $15.79 \%$, which was more than the average annual growth rate of fixed asset investment. The amount of real estate development investment is an important part of GDP accounting, and it is increasing year by year. This also reflects the prosperity of Guangzhou's real estate industry in recent years. See Figure 1.

Average price of commercial housing: From 2007 to 2017, the average selling price of commercial housing in Guangzhou increased from 8599 yuan per square meter to 16,905 yuan per square meter, with a growth rate of $96.59 \%$, and an average annual growth rate of $7.86 \%$. In 2010 , the real estate industry developed a boom, with a growth rate of $28.45 \%$, which made the average price of commercial housing begin to break through the 10,000-yuan mark. In 2012, the government's implementation of the purchase restriction policy has a certain impact on real estate. In the following years, the average price of commercial housing in Guangzhou has been increasing year by year. See Figure 2.

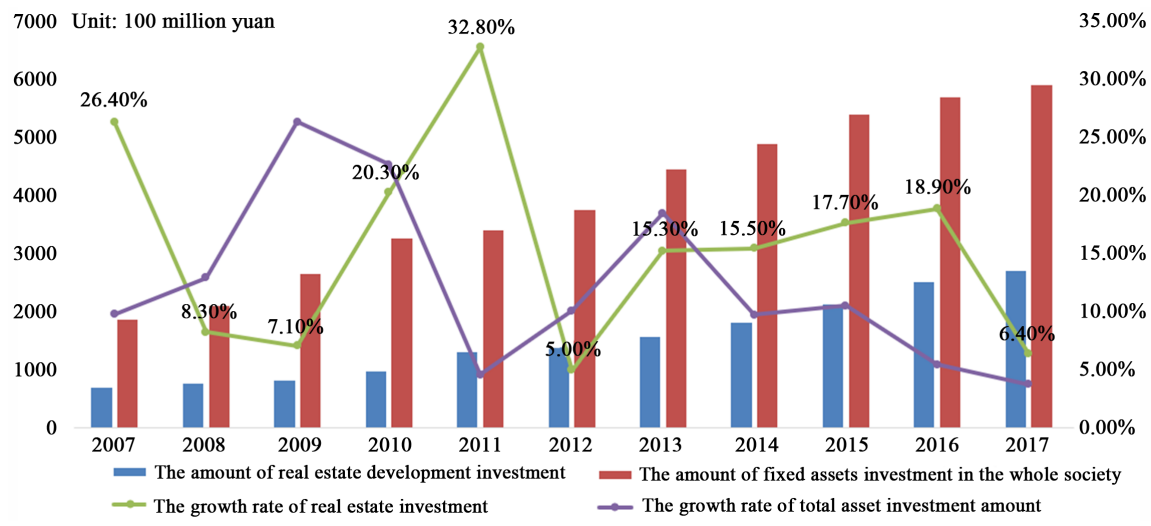

Figure 1. Investment in real estate and investment in fixed assets in Guangzhou.

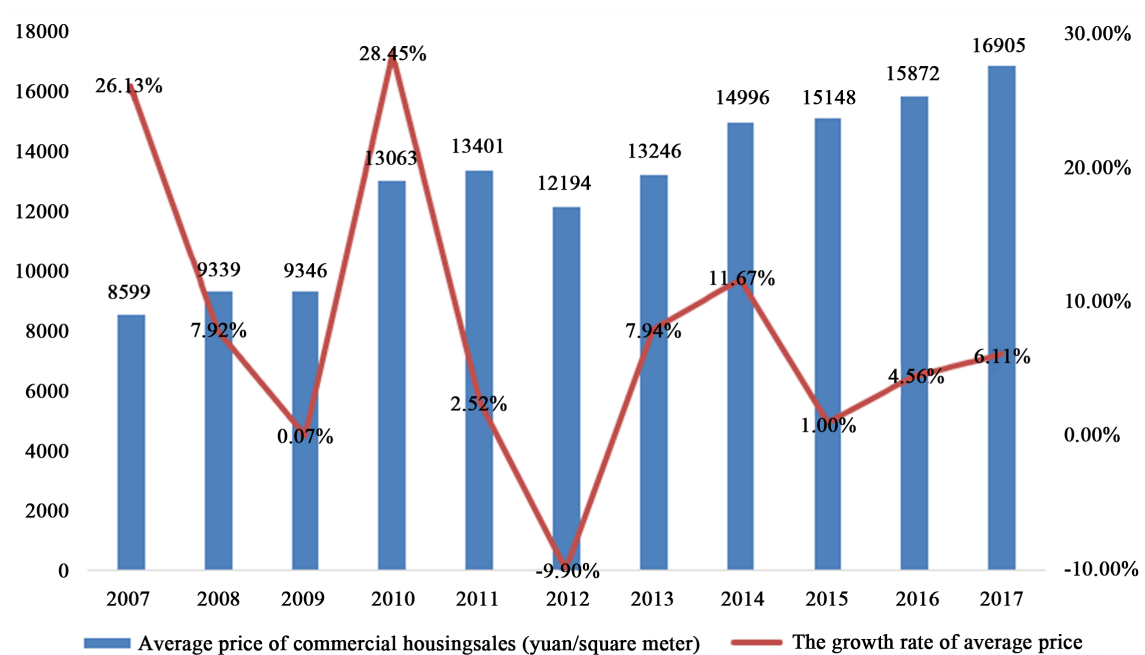

Figure 2. Average selling prices of commercial housing in Guangzhou. 
Figure 2 shows that the average price of the latest commercial housing is 16,905 yuan. Buethe prices of the districts such as Conghua and Huadu are far from those of Tianhe and Yuexiu. The average price of commercial housing in Tianhe District and Yuexiu District is above 30,000 in 2017, and some of the listings can reach as high as 70,000 in the CBD business circle. Although the disposable income of Guangzhou residents has also increased year by year, in the face of the rapid growth of commodity housing prices, the majority of residents, especially low- and middle-income people, cannot afford to bear high prices. Therefore, compared with income, the current housing prices in Guangzhou are still relatively high, ranking top in China.

\subsection{Real Estate Bubble Measure Based on a Single Indicator}

In order to conduct empirical research on the real estate bubble, the first task is to construct a measure of the real estate bubble. The selection of indicators refuses to be arbitrary, but needs to be constructed strictly according to the basis of representativeness, comprehensiveness, feasibility, and accessibility. The real estate bubble is related to the supply and demand, price, investment and other aspects of the real estate market [1]. Considering the source of the data and the possibility of its acquisition, it mainly constructs the real estate bubble measurement system from the perspectives of supply and demand, investment and credit. In this regard, this paper selects the ratio of house price to income, housing price growth rate/GDP growth rate, housing vacancy rate, investment growth rate/GDP growth rate, residential construction area/residential completion area, total real estate development investment/total social fixed assets investment. Using these six indicators to conduct a survey on the 2007-2017 Guangzhou real estate bubble. The basic data involved in this article are all from the Guangzhou Municipal Bureau of Statistics ${ }^{1}$.

The ratio of house price to income: The ratio of house price to income is used to measure the reasonableness of housing prices and the ability of residents to purchase houses. It is one of the important indicators for measuring the real estate bubble. The indicator refers to the ratio of housing price to the average annual income of urban households. It is a positive indicator. The smaller the indicator, the smaller the real estate bubble. In combination with this article, the average annual income of commercial housing is used to eliminate the average annual income of households. According to China's housing policy, the per capita housing area is 30 square meters, which is bought by the couples.

With reference to relevant research [1] and analysis of the real estate situation in China, this paper selects 10 as the critical value of the price-to-income ratio measured by the degree of bubble. The value is less than 10, and there is no bubble, which belongs to the safe area; 10 - 11 has a slight bubble, which belongs to the warning zone; there is a serious bubble above 11, which belongs to the dangerous zone.

${ }^{1}$ Basic data from Guangzhou Statistics Bureau: http://www.gzstats.gov.cn. 
According to the calculation results, the price-to-income ratio of Guangzhou in 2007-2017 is rising first and then decreasing. In particular, the ratio of house price to income in 2010 was 12.78 , which indicates that there is a serious real estate bubble phenomenon and the excessively height of house prices. This kind of phenomenon occurs because the Chinese government began to adopt an easing policy in 2008, social capital is highly liquid, and real estate development momentum is rapid, which provides support for the increase in housing prices. The ratio of house price to income in 2015-2017 has returned to normal, indicating that residents' ability to purchase houses has improved. See Table 1.

House price growth rate/GDP growth rate: The ratio of house price growth rate to GDP growth rate reflects the expansion of the real estate industry to the macro-real economy. GDP is seen as a development of the real economy and is a positive indicator. The higher the ratio, the higher the degree of real estate bubble. Use 1 as the critical value, in the safe zone within 1 range; in the warning zone within $1-2$, there is a slight bubble; the value is above 2 in the danger zone, indicating that the real estate bubble is serious.

Except for 2012, the ratio of house price growth rate to GDP growth rate is positive in all other years. In 2007, the ratio of household housing price growth rate to GDP growth rate in Guangzhou was 1.80 , which exceeded the bubble warning line and there was a slight real estate bubble. In 2010, it was 2.19, exceeding 2 , indicating that the real estate bubble is serious. However, the indicator fell back to the 1 range and is in a safe state from 2011 to 2017. See Table 2.

Housing vacancy rate: The vacancy rate of housing refers to the ratio of vacant housing area to total housing area at a certain point in time, which reflects the relationship between housing supply and demand. The housing vacancy rate is too high, which indicates that the supply exceeds demand, the real estate

Table 1. The ratio of house-to-income in Guangzhou from 2007 to 2017.

\begin{tabular}{|c|c|c|c|c|}
\hline Year & $\begin{array}{c}\text { Average price of } \\
\text { commercial housing } \\
\left(\text { yuan } / \mathrm{m}^{2}\right)\end{array}$ & $\begin{array}{c}\text { Urban resident } \\
\text { disposable income } \\
\text { (yuan) }\end{array}$ & $\begin{array}{l}\text { Ratio of house } \\
\text { price to income }\end{array}$ & Interval \\
\hline 2007 & 8599 & 22,469 & 11.48 & dangerous \\
\hline 2008 & 9339 & 25,317 & 11.07 & dangerous \\
\hline 2009 & 9346 & 27,610 & 10.16 & warning \\
\hline 2010 & 13,063 & 30,658 & 12.78 & dangerous \\
\hline 2011 & 13,401 & 34,438 & 11.67 & dangerous \\
\hline 2012 & 12,194 & 38,054 & 9.61 & safe \\
\hline 2013 & 13,246 & 42,049 & 9.45 & safe \\
\hline 2014 & 14,996 & 42,955 & 10.47 & warning \\
\hline 2015 & 15,148 & $46,734.6$ & 9.72 & safe \\
\hline 2016 & 15,872 & $50,940.7$ & 9.35 & safe \\
\hline 2017 & 16,905 & 55,400 & 9.15 & safe \\
\hline
\end{tabular}


Table 2. The ratio of housing price growth to GDP growth from 2007 to 2017.

\begin{tabular}{ccccc}
\hline Year & $\begin{array}{c}\text { House price } \\
\text { growth rate (\%) }\end{array}$ & $\begin{array}{c}\text { GDP } \\
\text { growth rate (\%) }\end{array}$ & $\begin{array}{c}\text { House price growth } \\
\text { rate/GDP growth rate }\end{array}$ & Interval \\
\hline 2007 & 26.13 & 14.50 & 1.80 & warning \\
2008 & 7.92 & 12.30 & 0.64 & safe \\
2009 & 0.07 & 11.50 & 0.01 & safe \\
2010 & 28.45 & 13.00 & 2.19 & dangerous \\
2011 & 2.52 & 11.00 & 0.23 & safe \\
2012 & -9.90 & 10.50 & -0.94 & safe \\
2013 & 7.94 & 11.60 & 0.68 & safe \\
2014 & 11.67 & 8.60 & 1.36 & safe \\
2015 & 1.00 & 8.40 & 0.12 & safe \\
2016 & 4.56 & 8.20 & 0.56 & safe \\
2017 & $6.11 \%$ & $7.00 \%$ & 0.87 & safe \\
\hline
\end{tabular}

market has a bubble phenomenon. This is actually not conducive to the intensive use of urban land, and is not conducive to the normal operation of the real estate market. For the calculation of housing vacancy rate, the method used in most studies is to use the vacant area of commercial housing to remove the sum of the completed areas of commercial housing for nearly three years [2]. According to Chinese studies, housing vacancy rate is in the normal range of $5 \%-10 \%$, indicating that social housing supply and demand balance; $10 \%-20 \%$ in the warning range, there is a slight real estate bubble; more than $20 \%$ in the danger zone, there is a serious real estate bubble, indicating There is a serious backlog of housing on the market.

According to Table 3, the housing vacancy rate in Guangzhou has been on the rise since 2007. From 2007 to 2008 , it was in the warning zone. And then it broke through the $20 \%$ mark in 2009 . Although it has risen and fallen in the next few years, it is still in the dangerous zone. In 2015-2017, housing vacancy rates were extremely severe. See Table 3.

Residential construction area/residential completion area: The ratio of residential construction area to residential completion area is an indicator reflecting the supply situation of the real estate market, and is a positive indicator. Compared to the housing vacancy rate, it is a short-term indicator that reflects each year. According to the construction of the project in Guangzhou, it is considered that there is no real estate bubble below 7; between 7 and 8 in the warning zone; 8 or more in the dangerous zone means that there will be a surplus of real estate supply, resulting in a real estate bubble.

According to the calculation results, the ratio of residential construction area to residential completion area is located in the safe area from 2007 to 2012.In 2013, the value began to be greater than 7 , and then it returned to the safe area. However, in the two years of 2016 and 2017, the value has risen to 8 , and there is a serious real estate bubble. See Table 4 . 
Table 3. Housing vacancy rates in Guangzhou from 2007 to 2017.

\begin{tabular}{ccc}
\hline Year & Housing vacancy rate (\%) & Interval \\
\hline 2007 & 15.77 & warning \\
2008 & 14.64 & warning \\
2009 & 27.03 & dangerous \\
2010 & 22.34 & dangerous \\
2011 & 26.22 & dangerous \\
2012 & 25.2 & dangerous \\
2013 & 27.51 & dangerous \\
2014 & 23.68 & dangerous \\
2015 & 38.52 & dangerous \\
2016 & 37.5 & dangerous \\
2017 & 38.66 & dangerous \\
\hline
\end{tabular}

Table 4. Ratio of residential construction area to residential area in Guangzhou.

\begin{tabular}{ccccc}
\hline Year & $\begin{array}{c}\text { Residential } \\
\text { construction area } \\
(10,000 \text { square meters })\end{array}$ & $\begin{array}{c}\text { Residential } \\
\text { completion area } \\
(10,000 \text { square meters })\end{array}$ & $\begin{array}{c}\text { Residential construction } \\
\text { area/residential } \\
\text { completion area }\end{array}$ & Interval \\
\hline 2007 & 5184.14 & 882.02 & 5.88 & safe \\
2008 & 5500.37 & 943.76 & 5.83 & safe \\
2009 & 5505.56 & 961.24 & 5.73 & safe \\
2010 & 6464.12 & 1094.59 & 5.91 & safe \\
2011 & 7704.34 & 1263.2 & 6.10 & safe \\
2012 & 7845.62 & 1290.79 & 6.08 & safe \\
2013 & 8939.06 & 1141.3 & 7.83 & warning \\
2014 & 9369.93 & 1919.46 & 4.88 & safe \\
2015 & 9345.57 & 1511.49 & 6.18 & safe \\
2016 & $10,061.92$ & 1202.24 & 8.37 & dangerous \\
2017 & $12,044.84$ & 1496.38 & 8.05 & dangerous \\
\hline
\end{tabular}

Investment growth rate/GDP growth rate: The ratio between the growth rate of investment and the growth rate of GDP is to compare the growth rate of real estate investment with the speed of real economic development. This indicator measures the extent of real estate bubbles from an investment perspective. It is generally believed that there is a real estate bubble when the indicator exceeds 2 , and there is a serious bubble when the value is above 2.5 .

According to the calculation results, except for the real estate bubble phenomenon in the three years of 2011, 2015 and 2016, the rest of the years are in a safe period. Among them, the ratio in 2011 reached 2.98, indicating that the real estate bubble is serious. See Table 5 . 
Table 5. Ratio of investment growth rate to GDP growth rate in Guangzhou from 2007 to 2017.

\begin{tabular}{ccccc}
\hline Year & $\begin{array}{c}\text { Investment } \\
\text { growth rate (\%) }\end{array}$ & $\begin{array}{c}\text { GDP } \\
\text { growth rate (\%) }\end{array}$ & $\begin{array}{c}\text { Investment growth } \\
\text { rate/GDP growth rate }\end{array}$ & Interval \\
\hline 2007 & 26.40 & 14.50 & 1.82 & safe \\
2008 & 8.30 & 12.30 & 0.67 & safe \\
2009 & 7.10 & 11.50 & 0.62 & safe \\
2010 & 20.30 & 13.00 & 1.56 & safe \\
2011 & 32.80 & 11.00 & 2.98 & dangerous \\
2012 & 5.00 & 10.50 & 0.48 & safe \\
2013 & 15.30 & 11.60 & 1.32 & safe \\
2014 & 15.50 & 8.60 & 1.80 & warning \\
2015 & 17.70 & 8.40 & 2.11 & warning \\
2016 & 18.90 & 8.20 & 2.30 & safe \\
\hline 2017 & 6.40 & 7.00 & 0.91 &
\end{tabular}

Real estate development investment/total social fixed assets investment:

The ratio of the amount of investment in real estate development to the amount of investment in fixed assets in the whole society is a measure of whether the annual investment structure of the real estate industry is reasonable and whether there is a serious expansion of the industry. This paper selects 40 as the critical value. If it exceeds 40 , it thinks that there is a real estate bubble; $40-45$ is in the warning zone; above 45 is in the dangerous zone, and it can be considered that the investment in development is too much, which leads to the unreasonable investment structure of the whole industry.

According to the calculation results, the ratio of the amount of investment in real estate development to the investment in fixed assets of the whole society is in a safe area from 2007 to 2015. In 2016, it was 44.11 and in the warning zone. In 2017 , it actually reached 45.66 , indicating that the real estate development and expansion is serious. See Table 6.

Comparison of the indicators: The results of the above-mentioned indicators of real estate bubble measurement are summarized. In general, it is not difficult to see that there are more obvious real estate bubbles in 2007, 2010, 2011, 2016 and 2017. Moreover, the degree of real estate bubble reflected by the housing vacancy rate is the most serious.

From the perspective of a certain indicator, it is difficult to make a unified comparison based on the angles and standards measured by each indicator. In order to compare the degree of real estate bubble and obtain objective information, the author will use the comprehensive index method to measure time series data. See Table 7. 
Table 6. Ratio of investment growth rate to GDP growth rate in Guangzhou from 2007 to 2017.

\begin{tabular}{ccccc}
\hline Year & $\begin{array}{c}\text { Real estate } \\
\text { development investment } \\
(100 \text { million yuan })\end{array}$ & $\begin{array}{c}\text { Urban fixed assets } \\
\text { investment } \\
(100 \text { million yuan })\end{array}$ & $\begin{array}{c}\text { Real estate development } \\
\text { investment/fixed } \\
\text { assets investment }\end{array}$ & Interval \\
\hline 2007 & 703.8 & 1863.34 & 37.77 & safe \\
2008 & 762.43 & 2104.56 & 36.23 & safe \\
2009 & 817.34 & 2659.85 & 30.73 & safe \\
2010 & 983.66 & 3263.57 & 30.14 & safe \\
2011 & 1306.74 & 3413.58 & 38.28 & safe \\
2012 & 1370.45 & 3758.39 & 36.46 & safe \\
2013 & 1579.68 & 4454.55 & 35.46 & safe \\
2014 & 1816.15 & 4889.50 & 37.14 & safe \\
2015 & 2137.59 & 5405.95 & 39.54 & safe \\
2016 & 2515.94 & 5703.59 & 44.11 & warning \\
2017 & 2702.89 & 5919.83 & 45.66 & dangerous \\
\hline
\end{tabular}

Table 7. Measurement indexes of real estate bubbles in Guangzhou from2007 to 2017.

\begin{tabular}{|c|c|c|c|c|c|c|}
\hline Year & $\begin{array}{c}\text { Ratio of } \\
\text { house price } \\
\text { to income }\end{array}$ & $\begin{array}{l}\text { House } \\
\text { price growth } \\
\text { rate/GDP } \\
\text { growth rate }\end{array}$ & $\begin{array}{c}\text { Housing } \\
\text { vacancy } \\
\text { rate }\end{array}$ & $\begin{array}{c}\text { Residential } \\
\text { construction } \\
\text { area/residential } \\
\text { completion area }\end{array}$ & $\begin{array}{l}\text { Investment } \\
\text { growth } \\
\text { rate/GDP } \\
\text { growth rate }\end{array}$ & $\begin{array}{c}\text { Real estate } \\
\text { development } \\
\text { investment/fixed } \\
\text { assets investment }\end{array}$ \\
\hline 2007 & serious & slight & slight & - & - & - \\
\hline 2008 & serious & - & slight & - & - & - \\
\hline 2009 & slight & - & serious & - & - & - \\
\hline 2010 & serious & serious & serious & - & - & - \\
\hline 2011 & serious & - & serious & - & serious & - \\
\hline 2012 & - & - & serious & - & - & - \\
\hline 2013 & - & - & serious & slight & - & - \\
\hline 2014 & slight & - & serious & - & - & - \\
\hline 2015 & - & - & serious & - & slight & - \\
\hline 2016 & - & - & serious & serious & slight & slight \\
\hline 2017 & - & - & serious & serious & - & serious \\
\hline
\end{tabular}

\subsection{Real Estate Bubble Measurement Based on Comprehensive Index}

The comprehensive index method was proposed by domestic scholar Liu Lin [3] and is a commonly used index synthesis method. First, the index data is sorted and divided by its critical value for infinite tempering to remove the influence between different units. After extracting each index coefficient by principal component method, the product of each index and coefficient is summed by 
weighting method. The final result is the real estate bubble index for each year. The operation process is as shown in Equation (1). When the index exceeds 1, it is considered to be a real estate bubble. In order to be more refined, a slight bubble is considered when the real estate bubble index is in the range of 1 to 1.2; a moderate bubble is considered in the range of $1.2-1.4$; a serious bubble is considered to exist in the above 1.4. See Table 8.

$$
I=\sum_{i=1}^{n} \frac{F_{i}}{S_{i}} W_{i}
$$

Among them, $I$ is the real estate economic bubble index; $F_{i}$ is the actual value of the single indicator; $S_{i}$ is the single indicator threshold; $W_{i}$ is the weight coefficient of each indicator; $n$ is the number of indicators, the value is 6 .

According to the results, the Guangzhou real estate bubble index showed an upward trend in 2007-2017. In the past decade, there have been real estate bubbles in most years, but the degree of bubbles has been different. In 2007, the value index of the real estate bubble in Guangzhou exceeded 1, indicating a bubble in the real estate market. However, affected by the global financial crisis, the composite index value has declined in 2008-2009. It can be seen from this that the government's easing policy has played a role, making the development of the Guangzhou real estate industry not completely in a downturn. On the contrary, due to these favorable conditions, the real estate market began to appear economic bubble in 2010-2011. After that, the development of the real estate industry in 2013-2017 was rapid, and the phenomenon of excessive housing prices was obvious to all. The existing real estate bubble has become more and more serious. Especially in 2016 and 2017, the Guangzhou Real Estate Composite Index has reached a high level of 1.49 or higher. It can be said that the housing prices of Guangzhou in recent years have made the middle and low income groups stagnate.

Table 8. The measurement of the real estate bubble comprehensive index in Guangzhou.

\begin{tabular}{ccc}
\hline Year & Real estate economic bubble index & Degree of bubble \\
\hline 2007 & 1.1604 & slight \\
2008 & 0.9204 & - \\
2009 & 0.9991 & - \\
2010 & 1.2859 & moderate \\
2011 & 1.1881 & slight \\
2012 & 0.8736 & - \\
2013 & 1.2303 & moderate \\
2014 & 1.1823 & slight \\
2015 & 1.3384 & moderate \\
2016 & 1.4956 & serious \\
2017 & 1.4954 & serious \\
\hline
\end{tabular}




\section{Analysis of the Causes of Real Estate Bubble}

According to empirical analysis, combined with the current real estate market, the characteristics of virtual capital are the basis for the formation of a real estate bubble. The virtual economy promotes and supports the formation of a real estate bubble [4]. Then why does it generate virtual capital? The discussion comes down to the following reasons.

\subsection{Supply and Demand Elasticity Imbalance}

The urbanization rate in Guangzhou has reached $86.14 \%$. Every year, a large number of migrant workers are influx. The number of registered immigrants was 180,600 last year. Moreover, because of the optimistic economic development in Guangzhou in recent years and the continuous increase in per capita disposable income, it is conceivable how great the demand for housing is. However, due to the nature of real estate, the construction period and return period in the development process are relatively long, which leads to the lag of the supply side reaction. The real estate industry is prone to imbalance between the demand side and the supply side, and lacks an elastic mechanism, resulting in a sharp rise of housing prices in the short term. These make the real estate bubble have the potential to sprout.

\subsection{Increase in Land Cost}

House prices are related to land prices, and the price increases are naturally inseparable from changes of investment costs. The limited and scarce nature of land resources should be considered in urban land planning. In order to pursue intensive and vertical use, there is less and less land available in the urban built-up area, and its price increase is inevitable. At the same time, this is also affected by the "defects" of land finance. The Chinese government relies too much on land finance, land transfer fees and real estate-related taxes, and their total amount is more than half of the fiscal revenue. Therefore, some local governments will be tempted by high land prices and are keen to sell land to maintain fiscal revenue in the short term, which has led to the hollowing out of regional economic development.

\subsection{Expected Speculation}

The action orientation of buyers will affect the direction of the real estate market. In addition to its own residential attributes, real estate also has the characteristics of value-added income, and its expected value-added space has great potential. So, the people with rich incomes who are willing to join the speculative ranks greatly stimulates the demand for housing. These houses are highly likely to become vacant houses, especially in bungalows and villa communities, which are prone to so-called "empty cities".

\subsection{Irrational Expansion of Financial Institutions}

Real estate development requires a lot of capital investment, and developers of- 
ten find financial institutions to integrate funds. In order to seek their own interests in the competitive market, financial institutions are also willing to put funds into real estate development. This will enable developers to develop projects in the event of insufficient funds, resulting in blind development. In order to recover the funds as soon as possible, the developer will take the action of "unfinished but salefirst", which is not conducive to the normal trading of the real estate market. Similarly, individual purchases can also be loaned to financial institutions. Once the threshold is set too low, it will attract more speculators who follow the trend blindly to boost housing prices.

\section{Conclusions}

This paper analyzes the development status of real estate industry in Guangzhou, and uses the real estate industry data from 2007 to 2017 to construct a measurement index system to detect the degree of real estate bubble. Based on the empirical results, it explores the genetic mechanism and proposes countermeasures to suppress the real estate bubble in the future.

During the period of 2007-2017, the investment of real estate industry in Guangzhou increased year by year, and the average price level of commercial housing was also at a high level. In the empirical study of measurement, both the single indicator and the comprehensive index method can reflect the real estate bubble in Guangzhou. The degree of real estate bubble in the past two years is also the most serious.

Through thinking and analysis, combined with the current development status of Guangzhou, its real estate bubble is often triggered by many aspects, including imbalance of supply and demand, increased land cost, expected speculation, and irrational expansion of financial institutions.

\section{Conflicts of Interest}

The author declares no conflicts of interest regarding the publication of this paper.

\section{References}

[1] Zhang, P.H. (2016) Analysis of Wuhan City Real Estate Bubble Measurement and Cause Mechanism. Wuahn Finance, 10, 43-46.

[2] Sun, J., Zheng, S.Q. and Liu, H.Y. (2005) International Comparison of Residential Vacancy Statistics and Its Reference Significance. Statistical Research, 8, 8-12.

[3] Liu, L., Zheng, S.Q. and Huang, Y. (2003) Method for Compiling the Measurement Coefficient of Real Estate Bubble. Chinese Real Estate, 6, 13-15.

[4] Xiao, M.Z. (2011) Research on Real Estate Bubble Measurement: Taking Beijing and Shanghai as Examples. Economic Research Reference, 33, 43-50. 